\title{
Žemès ūkio naudmenų ploto apskaita ir pokyčių analizė Lietuvoje
}

Agnẻ Bykovienè,

Darius Pupka,

Audrius Aleknavičius

Aleksandro Stulginskio universitetas, Studentu g. 11,

LT-53361 Akademija, Kauno $r$.

El.paštas: agnebykoviene@gmail.com; darius.pupka@gmail.com; audrius.aleknavicius@asu.lt
Straipsnyje nagrinëjamas žemès naudmenų apskaitos turinys ir jos vykdymo tvarka, analizuojami žemès ūkio naudmenų pokyčiai Lietuvoje ir šiuos pokyčius lemiantys veiksniai. Nustatyta priklausomybè tarp žemès panaudojimo žemès ūkio produkcijai auginti laipsnio ir žemès našumo bei vietovès reljefo. Išskirtos 23 kalvotų žemių savivaldybių teritorijos, kuriose dèl kalvoto-banguoto reljefo žemès naudojimo sąlygos yra prastesnès, santykinai daugiau nepanaudotų (nedeklaruotų) žemès ūkio naudmenų. Siekiant tiksliau nustatyti žemès ūkio naudmenų plotus, rekomenduojama panaudojant distancinius tyrimus rengti ir periodiškai atnaujinti kartografinę medžiagą su pažymètais žemès naudmenų kontūrais ir jos pagrindu vykdyti valstybinę žemès fondo apskaitą. Žemès informacinė sistema, apibūdinanti žemès ūkio paskirties žemès sklypų ūkines savybes, turètų apimti ir žemės naudojimo žemèlapių rengimą, o kalvotose teritorijose - ir hipsometrinius žemèlapius. Ši kartografinè medžiaga ir žemès naudmenų apskaitos duomenys turètų būti panaudojami tvarkant agrarines teritorijas ir planuojant žemès gerinimo darbus. Žemès ūkio naudmenų kartografavimas ir jų plotų tikslesnè apskaita labiausiai reikalinga kalvotose teritorijose bei urbanistinès plètros arealuose.

Raktažodžiai: žemès naudmenos, žemès ūkio naudmenos, kalvotos teritorijos, žemès našumo balas, žemès naudmenų kartografavimas, žemès fondo apskaita

\section{IVADAS}

Žemès ūkio naudmenų plotas ir jų kontūrų identifikacija kartografinejje medžiagoje yra svarbus rodiklis, reikalingas planuojant žemès ūkio veiklą ir žemès naudojimą ūkiuose bei ịvairiuose strateginio planavimo dokumentuose. Be to, šie duomenys turi būti pakankamai tikslūs, t. y. operatyviai atnaujinami ịvertinant vykstančius pokyčius. Administracinèms teritorijoms žemès ūkio naudmenų, taip pat kitų žemès naudmenų plotai Lietuvoje nustatomi remiantis kasmet vykdomos žemès fondo valstybinès apskaitos duomenimis. Papildoma informacija apie naudojamas žemès ūkio naudmenas dar gali būti gaunama iš Visuotinio žemès ūkio surašymo (Lietuvoje jis atliktas 2003 ir 2010 m.) bei iš kasmet skelbiamų žemès ùkio naudmenų ir pasèlių deklaravimo statistinių rodiklių.
Norint tirti žemės naudmenų pokyčius būtina jų kiek i̇manoma tikslesnè apskaita. Didžiausias poreikis yra nustatyti žemès ūkio naudmenų, pagrindinès gamybos priemonès, reikalingos žemès ūkio produkcijai išauginti, plotus šalyje, administracinèse teritorijose ir ūkiuose ar kitose vietovèse. Žemès ūkio naudmenų apskaita aktuali dèl kelių svarbių priežasčių. Pirma, šių naudmenų plotas yra svarbus palyginamasis rodiklis, apibūdinantis svarbaus žemès ūkio gamybos komponento apimtis, santyki su kitomis gamybos priemonèmis, žemès naudojimo intensyvumą ir potencines galimybes. Antra, racionaliam žemès naudojimui būtinas kuo detalesnis žemès gamtinių ir ūkinių savybių tyrimas, išreiškiamas kartografinèje medžiagoje sugretinant ìvairių tyrimų metu parengtas informacinių duomenų bazes (sluoksnius) apie žemès ūkio naudmenų kontūrus, dirvožemius, reljefą, melioracinius įrenginius, kelių ir pastatų išsidèstymą. 
Trečia, žemès naudmenos yra ribojamos reikalavimų ne tik intensyvinti gamybą pagal dirvožemio savybes geriausiai atitinkančią ūkių specializaciją, bet ir kraštovaizdžio ekologinès ịvairovès didinimo, aplinkos apsaugos, urbanistinès plètros reikalavimus. Juos tinkamai suderinti tarpusavyje galima tik teritorijų planavimo procese, turint tikslią informaciją apie žemès ūkio naudmenų išsidėstymą bei ìvykusius pokyčius ir juos lemiančius veiksnius.

Analizuojant agrarinèse vietovèse vykstančius procesus atliktuose moksliniuose tyrimuose apibūdinama žemès ūkio naudmenų raida ir struktūra Baltijos šalyse, vykę pokyčiai prieš ir po įstojimo ị Europos Sąjungą (Šiupinytè, Mačiulytė, 2013), žemès ūkio naudmenų kaita pagal teritorinius ypatumus. Lietuvoje, kaip ir beveik visose šalyse, pastebima žemès ūkio naudmenų mažèjimo tendencija (Stravinskienè, 2006). Žemès ūkio ir miškų ūkio žemès pokyčius Lietuvoje 1982-2002 m. laikotarpiu analizavę B. Kavaliauskienè ir M. E. Tarvydiené (2005) nustaté, jog ariamosios žemès plotų šalyje minètu laikotarpiu sumažejo 118 tūkst. ha, pievų ir natūralių ganyklų - 89,1 tūkst. ha, o miškų padaugejjo 44,9 tūkst. ha. Ariamoji žemé daugiausia sumažèjo Žemaitijos aukštumų rajonuose. Išnagrinejus urbanizuotų teritorijų ir miškų plètros tendencijas nustatyta, kad žemès ūkio naudmenų plotas Lietuvoje kasmet gali sumažèti 3,7 tūkst. ha dèl naujų statybų ir 3,6 tūkst. ha dèl miškų ploto padidejjimo (Aleknavičius, Valčiukienè, 2011). Žemès ūkio veiklai naudojamų teritorijų raidą nenašių žemių savivaldybèse analizavę E. Abalikštienè ir P. Aleknavičius (2013) nustatè, jog 32 \% šalies agrarinių teritorijų dèl nenašių žemių turi mažiau palankias ūkininkavimo sąlygas, jose deklaruojamų žemés ùkio naudmenų plotas sudaro tik $72 \%$ statistinių žemès ūkio naudmenų.

Vadovaujantis žemès fondo valstybinès apskaitos duomenimis, nustatyta, jog žemès naudojimo intensyvumui įtakos turëjo valstybės agrariné politika ir jos igyvendinimo pasekmès, îvykę esminiai socialiniai ir ekonominiai pokyčiai. Per 1948-1989 m. laikotarpi žemès ūkio naudmenų plotas Lietuvoje vidutiniškai kasmet mažèjo po 18,9 tūkst. ha. Per paskutiniosios žemès reformos laikotarpi (1990-2005) žemès ūkio produkcijai išauginti panaudotų žemès ūkio naudmenų plotas sumažèjo 777 tūkst. ha (kasmet mažèjo po 51,8 tūkst. ha), o ariamojoje žemèje įrengtu pievu ir ganyklu šalyje atsirado neproporcingai daug (Aleknavičius, 2007). Pagrindiniai veiksniai, turintys įtakos žemès ūkio naudmenų naudojimo intensyvumui: ploto vienetui tenkanti augalininkystès produkcijos vertè, valstybès paramos žemès ūkio veiklos subjektams apimtys ir vidutinis ūkio žemènaudos dydis, kaimų nykimas (ypač Rytų Lietuvoje) ir spartus kaimo gyventojų skaičiaus mažejimas (Aleknavičius, Aleknavičius, 2010). Kiti veiksniai, darantys poveiki ariamosios žemès naudojimui Lietuvoje, ir nepanaudojimo priežastys yra melioracijos sistemų defektai, mažos ūkinès vertès žemès, nepalanki ūkių struktūra (Stravinskienė, 2002).

Pastaraisiais metais naudojamų (deklaruojamų) žemès ūkio naudmenų plotas pradejo didèti, tačiau ši procesą lètina valstybès skatinamas mišku ìveisimas žemès ūkio paskirties žemèje. P. Aleknavičius (2012) nustatè, kad per 19902012 m. laikotarpi naudojamų žemès ūkio naudmenų plotas Lietuvoje sumažèjo 21,6 \%, o miškų plotas padidèjo $8,3 \%$. Norint stabilizuoti žemès ūkio naudmenų ploto mažejimą rekomenduojama, kad santykis tarp žemès ùkio naudmenų ir miškų būtų nustatomas rengiant kompleksinius teritorijų planavimo dokumentus, o žemès ūkio naudmenų teisinè apsauga turètų būti analogiška miško žemès apsaugai. Tačiau, kaip savo tyrimuose nustate P. Aleknavičius, A. Aleknavičius ir D. Juknelienè (2014), Lietuva turi potencines galimybes atkurti buvusi žemès ūkio gamybos lygi ir padidinti intensyviai naudojamų žemès ūkio naudmenų plotus. Tik būtinas kryptingas valstybinis reguliavimas, kurio vienu iš pagrindinių svertų būtų žemès ūkio gamybos apimčių padidinimas ịtraukiant $\mathfrak{i}$ intensyvią žemès ūkio veiklą potencialiai derlingas apleistas žemes, taip pat žemès ūkio naudmenų vertingųjų savybių gerinimas panaudojant dirvožemių tyrimo ir kitus žemès informacinès sistemos duomenis. Iš viso (Aleknavičius, Stravinskienè, 2011) žemès ūkio naudmenų plotą Lietuvoje, įsavinus apleistas žemès ūkio naudmenas, galima padidinti iki 3 mln. ha. Tačiau institucijos, administruojančios žemès ùkio ir kaimo plètrą, turètų didesni demesi skirti probleminiams Rytu Lietuvos zonu arealams - numatyti priemones, galinčias stabilizuoti žemès ūkio gamybos ir kaimo gyventoju skaičiaus mažèjimą. 
Žemès naudmenų apskaitą kaimo vietovèje analizavęs P. Aleknavičius (2003) pažymi, jog žemès naudmenų pokyčiai priklauso nuo komplekso veiksnių: kaimo gyventojų skaičiaus, valstybès agrarinès politikos bei žemès ūkio produkcijos poreikio, mokslinès ir techninès pažangos. Išskirti periodai, kurių metu žemès naudmenų kitimą lèmé skirtingos sąlygos: laikotarpis iki II pasaulinio karo, II pasaulinis karas ir pokario metai (1940-1950), stambių žemès ūkio įmonių formavimosi laikotarpis (1950-1970), intensyvios žemès ūkio gamybos laikotarpis (1970-1990), žemès ūkio restruktūrizavimo laikotarpis (prasidèjęs 1991-1992). Žemès fondo duomenų nustatymo bei jų tipologijos ypatumus skirtingais XX a. laikotarpiais įvertinę R. Rutkauskaitė ir J. Milius (2007) nustatè, kad žemès fondo apskaita priklauso nuo dviejų pagrindinių principų: valstybės poreikių ir apskaitos duomenų nustatymo techninio lygio. XX a. žemès fondo detalumas nebuvo vienodas, nes keitessi techninis lygis ir valstybès poreikiai turèti vienokią ar kitokią informaciją apie žemès fondą. Tarpukario laikotarpiu turèti tikslią apskaitą nebuvo galimybių, todèl apskaita vykdyta apklausų metodu, ją atliko statistikos žinybos, o jos nesinaudojo kartografine medžiaga. Esant valstybinei žemès nuosavybei, valstybė buvo suinteresuota turèti išsamius duomenis apie žemès fondą, be to, galimybès tai padaryti padidejo, pasitelkus aerofotografavimą. Nepriklausomybès laikotarpiu (nuo 1990) pasikeitus valstybès poreikiams tiksli apskaita pasidarè neaktuali. 1995 ir 2005 m. pagamintos naujos aerofotonuotraukos, tačiau jos nebuvo dešifruotos ir naudojamos rengiant ar tikslinant žemès fondo statistiką (Rutkauskaitè, Milius, 2007).

Ivertinus keliamas problemas, šiame straipsnyje atliktų tyrimų tikslas - išanalizuoti žemès naudmenų kartografavimo bei apskaitos raidą ir žemès ūkio naudmenų ploto pokyčius Lietuvos administracinèse teritorijose.

Keliami uždaviniai:

- išnagrinèti žemès naudmenų kartografavimo ir apskaitos vykdymo tvarkos pokyčius;

- nustatyti veiksnius, turinčius įtakos žemès ùkio naudmenų ploto pokyčiams administracinèse teritorijose;

- išnagrinèti žemès ūkio naudmenų kartografavimo ir tikslios apskaitos poreikị kalvotų agrarinių teritorijų savivaldybėse.

\section{TYRIMŲ METODAI IR SĄLYGOS}

Darbe taikyti matematiniai statistiniai metodai, duomenų analizè ir abstrahavimas. Pagrindiniai duomenys tyrimui gauti iš Nacionalinès žemès tarnybos, VI Valstybès žemès fondo, VI Registru centro, Visuotinio žemès ūkio surašymo rodiklių, Statistikos departamento, Nacionalinès mokejjimo agentūros. Analizuojant žemès ūkines savybes pasinaudota leidinio "Lietuvos žemès našumas“ (Lietuvos..., 2011) duomenimis.

\section{TYRIMŲ REZULTATAI IR JŲ APTARIMAS}

\section{Žemès naudmenų kartografavimo raida}

Žemès naudmenos - tai žemès plotai, besiskiriantys nuo kitų žemès naudmenų gamtinemis ir ūkinèmis savybèmis. Šis apibrěžimas, pateiktas Lietuvos Respublikos žemès įstatyme ${ }^{1}$, išreiškia tik žemès naudmenos rūšies nustatymo principą, kuriuo turi būti vadovaujamasi atliekant techninius veiksmus - išskiriant vietovejje konkretų žemès ūkio naudmenos sklypą ir pažymint jo ribas kartografinejje medžiagoje.

Analizuojant žemès sklypų planų ir didesnèms teritorijoms rengiamų topografinių žemèlapių ar kitokių planų, kuriuose žymimi žemès naudmenų kontūrai (šią kartografinę medžiagą sąlyginai galima vadinti žemès naudojimo žemèlapiais), sudarymo praktinę patirti, galima teigti, kad pagrindinemis gamtinemis savybėmis yra žemès tinkamumas augalams ir žmogaus ūkinès veiklos poveikio (antropogenizavimo) laipsnis. Atskiras žemės naudmenų rūšis sudaro: 1) žemès plotai, kuriuose yra natūraliai susiformavę arba dirbtinai sukurti vandens telkiniai (upès, upeliai, ežerai, sureguliuoti upeliai ir grioviai, vandens saugyklos, tvenkiniai ir kūdros); 2) natūralią būklę išlaikę žemès plotai (pelkès, nenaudojami žemès plotai); 3) savaime apaugę arba žmogaus pasodinti miškai, medžių ir krūmų želdiniai; 4) teritorijos su žemès ūkio augalams augti tinkamais dirvožemiais, žmogaus pagerintos ir pritaikytos naudoti žemès ūkio veiklai (žemès ūkio naudmenos); 5) žmogaus veiklos labai pakeistos teritorijos, iš dalies praradę derlingojo dirvožemio sluoksni ar kitas gamtinio kraštovaizdžio savybes (teritorijos, naudojamos

\footnotetext{
${ }^{1}$ Lietuvos Respublikos žemès įstatymo pakeitimo ịstatymas. 2004 m. sausio 27 d. Nr. IX-1983. Valstybès žinios. 2004. Nr. 28868.
} 
išdèstyti pastatus, kelius ir kitus statinius bei eksploatuoti naudingąsias iškasenas, kiemus ir aikšteles). Žemès ūkinès savybès papildomai apibūdina teritorijos panaudojimo ypatumus. Žemès ūkio naudmenų plotai dèl drègmès pertekliaus, nenašių dirvožemių ar sudėtingo reljefo netinkami naudoti vienmečių žemès ūkio augalų pasèliams, naudojami bei apskaitomi pievomis ir ganyklomis, vaismedžiais ir vaiskrūmiais apsodinti plotai - sodais, kitos žemés ūkio naudmenos - ariamąja žeme. Žemès sklypai, kuriuose auga miško medžiai, apskaitomi mišku tik jeigu jie atitinka miškų ùkio veiklai nustatytas sąlygas. Atsižvelgiant ị teritorijų esamą naudojimą, žmogaus veiklos žymiai pakeistos teritorijos skirstomos ị kelius, užstatytas teritorijas, pažeistą žemę ir kitą nenaudojamą žemę.

Žemès naudmenų rūšys ir jų kontūrų ribos nustatomos (kartografuojamos) rengiant žemès sklypu planus ir žemès naudojimo žemèlapius. Tam naudojami ortofotoplanai (parengti distanciniu tyrimų metu atliktų fotonuotrauku pagrindu) bei vietovejje vykdoma žemès naudmenų ir situacijos instrumentinè nuotrauka. Kadangi žemès naudmenų kontūrų žymejjimas žemès naudojimo žemèlapiuose ir jų periodiškas tikslinimas reikalauja daug darbo sąnaudų, ivvairiais laikotarpiais buvo siekiama kartografuoti ir apskaityti tik tas žemès naudmenas, kurios reikalingos statistinei informacijai ir valstybès valdymo priemonèms igyvendinti. Tarpukario Lietuvoje rengiant žemètvarkos projektus ir žemès sklypų planus daugiausiai buvo žymima tik šios žemès naudmenos: ariamoji žemė, pievos, sodybos, keliai, miškai, pelkès, kitos netinkamos žemès. Nuo 1977 iki 1989 m. Lietuvoje žemès apskaita buvo vykdoma pagal valstybinio žemès kadastro tvarkymo reikalavimus ${ }^{2}$, todèl žemès naudmenų apibūdinimas buvo ypač detalus, nurodomi netgi antriniai žemès ir miško plotų požymiai³. Iš šių duomenų pokyčių buvo galima spręsti apie žemès gerinimo ar jos pablogèjimo tendencijas. Po 1990 m. žemès fondo skirstymas pagal žemès naudmenas buvo supaprastintas - paliktos tik

21977 m. birželio 10 d. TSRS Ministrų Tarybos nutarimas Nr. 501 „Dèl valstybinio žemès kadastro vedimo tvarkos“.

3 Ariamosios žemès, dirvonų, pievų ir ganyklų buvo žymimas akmenuotumas: silpnas, vidutiniškas, stiprus ir labai stiprus. Pievos ir ganyklos dar buvo skirstomos ị kupstuotas (silpnai, vidutiniškai ir stipriai), krūmuotas (silpnai, vidutiniškai ir stipriai), apaugusias mišku (silpnai, vidutiniškai ir stipriai). tos žemès naudmenų rūšys, kurių pakeitimo reguliavimą nustato norminiai teisès aktai. Per šiuos laikotarpius žemès naudmenų kartografavimui taikomų reikalavimų kitimas palygintas 1 lentelëje.

Atskirų laikotarpių žemès fondo apskaitą galima vertinti šiais aspektais: kiek ji atspindejo faktinę situaciją ir kaip ji buvo panaudojama žemès valdymo tikslams.

Tarpukario Lietuvoje kartografinès medžiagos buvo tik tiek, kiek toje vietoje jos reikejo rengiant žemètvarkos projektus (parceliuojant dvarus, skirstant kaimus $\mathfrak{i}$ vienkiemius, atliekant žemès valdų padalijimus ar kitokius žemès sklypų ribų keitimo darbus). Visa ši medžiaga buvo panaudojama apmokestinant žemes, o žemés ūkio surašymo laikotarpiu - statistinei apskaitai šalies mastu. Specialus žemès kartografavimas, pažymint žemès naudmenų kontūrus, nebuvo vykdomas.

1963-1989 m. laikotarpiu Lietuvoje žemès naudmenu apskaita buvo vykdoma vadovaujantis valstybinio žemès kadastro tvarkymo reikalavimais, administracinių teritorijų žemès naudmenų inventorizacijos duomenimis bei kasmetinès („einamosios") žemès apskaitos duomenimis.

Žemès naudmenų inventorizacijos darbų kompleksą sudarè:

1. Aerofotonuotrauka ir jos pagrindu gaminami fotoplanai M 1: 10000.

2. Fotoplanų dešifravimas vietoveje.

3. Skaidrių braižymas atskiroms stambioms žemènaudoms ir teritorijoms (žemès ūkio įmonèms, miškų girininkijoms, durpynams, miestams, miesto tipo gyvenvietèms ir kt.).

4. Žemès naudmenų kontūrų plotų skaičiavimas, parengiant žemès naudmenų eksplikacijas pagal visas stambių teritorijų ir jose esančių ịvairią paskirti turinčiu žemès naudotojų (juridinių asmenų) žemènaudas.

5. Administracinių teritorijų (rajonų ir miestų) žemės naudmenų inventorizacijos domenų parengimas (sudarius žemès naudmenų plotų balansą) ir patvirtinimas. Rengiant suvestinius duomenis nustatomi ir pagrindžiami pokyčiai, ịvykę per laikotarpi nuo praejusios žemès naudmenų inventorizacijos (paprastai - per 10 metų).

Kasmetinis žemės naudmenų plotų patikslinimas buvo vykdomas tik tose vietovèse, kur žemès naudmenos pakito dèl teisès aktais reglamentuojamos žmogaus veiklos - melioracijos projektų vykdymo, miškų sodinimo, žemès perdavimo eksploatuoti 
1 lentelè. Kartografuojamos žemès naudmenos ir jų požymiai rengiamuose žemės sklypų planuose bei teminiuose žemèlapiuose

Table 1. Mapped farming lands and their features in land parcel plans and thematic maps

\begin{tabular}{|c|c|c|c|}
\hline \multirow[b]{2}{*}{$\begin{array}{l}\text { Žemès naudojimo } \\
\text { pobūdis } \\
\text { Land use }\end{array}$} & \multicolumn{3}{|c|}{$\begin{array}{l}\text { Žemès naudmenos pavadinimas pagal jų žymèjimą ir (arba) apskaitą } \\
\text { reglamentuojančius teisès aktus } \\
\text { Name of farming land by its legislation of marking and (or) registration }\end{array}$} \\
\hline & \begin{tabular}{|} 
pagal 19200130 \\
Žemès ūkio ir \\
valstybės turtų \\
ministro ir ŽŪM \\
Žemės tvarkymo ir \\
matavimo depar- \\
tamento direkto- \\
riaus patvirtintą \\
instrukciją („Lietu- \\
vos valstybès planu \\
žymès") \\
By instructions is- \\
sued by the Minis- \\
ter of Agriculture \\
and State Assets \\
and Director of \\
the Department of \\
Land Management \\
and Measurement \\
under the Ministry \\
of Agriculture (Plan \\
Marks of Lithuania) \\
in 30.01.1920
\end{tabular} & $\begin{array}{c}\text { pagal reikalavimus inventorizuoti žemès } \\
\text { naudmenas ir tvarkyti valstybinio žemès } \\
\text { kadastro knygas } \\
\text { (iki 1989) } \\
\text { By the requirements for farming land } \\
\text { inventorization and management of state } \\
\text { land cadastre books (until 1989) }\end{array}$ & $\begin{array}{l}\text { pagal LR Vyriausybės } \\
20020415 \text { nutarimu } \\
\text { Nr. } 534 \text { patvirtintus } \\
\text { Lietuvos Respublikos } \\
\text { Nekilnojamojo turto } \\
\text { kadastro nuostatus bei } \\
\text { LR žemės ūkio minis- } \\
\text { tro } 20020807 \text { isakymu } \\
\text { Nr. } 302 \text { patvirtintą } \\
\text { Žemès valstybinės ap- } \\
\text { skaitos tvarką } \\
\text { By regulations of the } \\
\text { Real Estate Cadastre of } \\
\text { the Republic of Lithua- } \\
\text { nia approved by Govern- } \\
\text { ment Order No. } 534 \\
\text { on } 15.04 .2002 \text { and the } \\
\text { State Land Registration } \\
\text { Procedure approved by } \\
\text { Order No. } 302 \text { of Min- } \\
\text { ister of Agriculture on } \\
\text { 07.08.2002 }\end{array}$ \\
\hline
\end{tabular}

Periodiškai dirbama ir naudojama (arba galima naudoti) pasèliams žemè Periodically cultivated or used land

Arimas; dirvonas; daržas

Arable land; fallow; garden
Ariamoji žemé; dirvonai Arable land; fallow
Ariamoji žemè

Arable land for crops

\section{Vaismedžiais ir \\ vaiskrūmiais apso- dinta žemè \\ Land under orchards and fruit trees}

\section{Vaisių sodas Orchard}

Daugiamečiai sodiniai: pramoniniai ir visuomeniniai sodai, sodai sodybose, uogynai, vaismedžių medelynai Perennial plantations: industrial and public orchards, orchards near house, berry plantations, nursery garden for orchards
Sodai

Gardens

\begin{tabular}{|c|c|c|c|}
\hline $\begin{array}{l}\text { Šienavimui naudo- } \\
\text { jamos žemès ūkio } \\
\text { naudmenos } \\
\text { Farming lands used } \\
\quad \text { for mowing }\end{array}$ & $\begin{array}{l}\text { Pieva; pieva su } \\
\text { kupstais; pieva su } \\
\text { krūmais; šlapia pieva } \\
\text { Meadow: humpy; } \\
\text { bushy; wet }\end{array}$ & $\begin{array}{l}\text { Pievos: užliejamos, iš jų kultūrinès; } \\
\text { sausminès, iš jų kultūrinès ir grynos; } \\
\text { pelkètos } \\
\text { Meadows: wet, of them cultural; dry, of them } \\
\text { cultural and natural; swampy }\end{array}$ & $\begin{array}{c}\text { Pievos } \\
\text { Meadows }\end{array}$ \\
\hline
\end{tabular}

\footnotetext{
Ganymui naudojamos žemès ūkio naudmenos

Farming lands used for pasture
}

Ganykla; ganykla šlapia ir su krūmais Pastures; wet pastures, bushy pastures
Ganyklos: sausminės, iš jų kultūrinès ir grynos; pelkètos Ganyklos

Pastures: dry, of them cultural and natural; swampy

Pastures 
Miško auginimui naudojama žemè Land used for forest
Maišytasis miškas; lapuočių miškas; eglynas; pušynas; ąžuolynas; iškirstas miškas

Mixed forest; leafy forest; spruce forest; pine forest; cut forest

\section{Miškai:}

- apaugę mišku, iš jų miško kultūros; nesusivèrę miško kultūros - neapaugę mišku, iš jų retmès, degimai ir žuvusios

kultūros, kirtimai (neapželdintos biržès), laukymès ir dykvietès (dykynès)

$$
\text { - miško medelynai }
$$

Forests:

Miškas

Forest

- grown by trees, of them with forest species, without them

- not grown by trees, of them emptiness, burnings, lost species, clearings - nursery garden for forests
Medžiais ir krūmais apauge ar apsodinti ne miško žemès plotai

Not a forest land grown by trees and bushes
Krūmai; augalų sodas (parkas)

Bushes; tree gardens (parks)
Medžių ir krūmų želdiniai (iš viso, iš jų):

- sodų, kelių, geležinkelių apsauginiai

$$
\text { želdiniai; }
$$

$$
\text { - krūmai; }
$$

- medžiai ir medžių grupès

Growings of trees and bushes: of them - gardens, roads, railways protection growings;

\begin{tabular}{|c|c|c|c|}
\hline $\begin{array}{c}\text { Žemès plotai su } \\
\text { būdinga pelkine } \\
\text { augalija } \\
\text { Land with character- } \\
\text { istic swamp vege- } \\
\text { tation }\end{array}$ & $\begin{array}{c}\text { Pelkè lygi, } \\
\text { šienaujama; pelkè } \\
\text { su kupstais; pelkè } \\
\text { su durpėmis; pelkè } \\
\text { samanota } \\
\text { Swamp smooth, for } \\
\text { mowing; humpy; } \\
\text { with peat; mossy }\end{array}$ & $\begin{array}{l}\text { Pelkès (iš viso, iš jų): } \\
\text { - aukštapelkès; } \\
\text { - tarpinès pelkès; } \\
\text { - žemapelkès } \\
\text { Swamps: of them: } \\
\text { - upland swamp; } \\
\text { - mediate swamp; } \\
\text { - lower swamps }\end{array}$ & $\begin{array}{l}\text { Pelkès } \\
\text { Swamps }\end{array}$ \\
\hline
\end{tabular}

$$
\text { - bushes; }
$$

- groups of trees and bushes
Žemès plotai, naudojami pastatams, aikštelèms ir kiemams Land used for buildings and yards
Pastatai, kiemai, gatvès ir aikštès: - gamybiniai centrai, ūkinès sodybos, gatvès ir aikštès;

- visuomeniniai pastatai;

Sodyba; kiemas Homestead; yard
- pastatai, kiemai kitose sodybose

Buildings, yards, streets and squares:

- farming centres, streets and squares; - public buildings;

\section{Medžių ir krūmų} želdiniai

Growings of trees and bushes

- buildings, yards in other homesteads

Užstatytos teritorijos

Built-up territories

Geležinkelis; plentas; vieškelis; lauko ke-

Ivairios paskirties lias; šunkelis; gatvès Keliai, išvaros, kvartalinès, priešgaisrinès ir keliai Railroads; road; road kitos iškirstos juostos Keliai Roads with gravel pavement, field road,

Roads, quartal, anti-fire and other cut strips

Roads 
1 lentelè (tęsinys)

Table 1 (continued)

\begin{tabular}{|c|c|c|c|}
\hline $\begin{array}{l}\text { Paviršiniai vandens } \\
\text { telkiniai } \\
\text { Surface water bodies }\end{array}$ & $\begin{array}{l}\text { Upe; ežeras; tven- } \\
\text { kinys; upelis; grioviai } \\
\text { River; lake; pond; } \\
\text { small river; ditch }\end{array}$ & $\begin{array}{c}\text { Vandenys: } \\
\text { - upés ir upeliai; } \\
\text { - ežerai; } \\
\text { - vandens talpyklos, tvenkiniai ir kiti dirb- } \\
\text { tiniai vandens telkiniai; } \\
\text { - kanalai, kolektoriai ir grioviai } \\
\text { Waters: } \\
\text { - rivers and small rivers; } \\
- \text { lakes; } \\
\text { - water reservoirs, ponds, other artificial } \\
\text { waters; } \\
\text { - channels, collectors, ditches }\end{array}$ & $\begin{array}{l}\text { Vandenys } \\
\text { Waters }\end{array}$ \\
\hline $\begin{array}{l}\text { Žemè, dèl } \\
\text { technogeninès } \\
\text { veiklos prara- } \\
\text { dusi derlingaji } \\
\text { dirvožemio sluoksni } \\
\text { Land with lost fertile } \\
\text { soil due to techno- } \\
\text { genic activity }\end{array}$ & \multirow{2}{*}{$\begin{array}{l}\text { Molio duobės; } \\
\text { smèlio duobės, } \\
\text { smiltynai; žvyro } \\
\text { duobès, žvyrynai; } \\
\text { kalnai ir daubos } \\
\text { Clay pits; sand pits; } \\
\text { gravel pits; } \\
\text { hills and hollows }\end{array}$} & $\begin{array}{c}\text { Pažeistos žemès: } \\
\text { - irrengiant naudingujjų iškasenų karjerus, iš } \\
\text { jų eksploatuojami karjerai; } \\
\text { - eksploatuojant durpynus; } \\
\text { - vykdant statybas bei kitus darbus } \\
\text { Damaged lands: } \\
\text { - preparing mineral quarries, of them used } \\
\text { quarries; } \\
\text { - exploiting peat; } \\
\text { - making constructions or other works }\end{array}$ & $\begin{array}{l}\text { Pažeista žemè } \\
\text { Damaged land }\end{array}$ \\
\hline $\begin{array}{l}\text { Kita žemé, netinka- } \\
\text { ma naudoti žemès } \\
\text { ūkio veiklai } \\
\text { Other land which } \\
\text { cannot be used for } \\
\text { agriculture }\end{array}$ & & $\begin{array}{c}\text { Kitos žemès: } \\
\text { - smèlynai, žvyrynai; } \\
\text { - griovos; } \\
\text { - kitos žemès ükyje nenaudojamos žemès } \\
\text { Other lands: } \\
\text { - sands, gravel pits; } \\
\text { - ravines; } \\
\text { - other lands not used for agriculture }\end{array}$ & $\begin{array}{l}\text { Kita nenaudojama žeme } \\
\text { Other unused land }\end{array}$ \\
\hline $\begin{array}{l}\text { Kitos žemès naud- } \\
\text { menos } \\
\text { Other lands }\end{array}$ & & $\begin{array}{c}\text { Melioruojama žemè (priimta eksploatacijai, } \\
\text { bet neisavinta) } \\
\text { Ameliorated land (taken into exploitation, } \\
\text { but not cultivated) }\end{array}$ & \\
\hline
\end{tabular}

naudingąsias iškasenas ir statyti ịvairios paskirties pastatus, teritorijos panaudojimo hidrotechninių objektų statybai.

Minima valstybinių įmonių ir valstybès lěšomis atliekamų darbų tvarka sudare galimybes rengti bei nuolat atnaujinti kokybišką kartografinę medžiagą (žemėnaudų planai buvo naudojami rengiant žemètvarkos projektus, planuojant teritorijas, įvairių su žeme susijusių objektų analizę) bei užtikrino pakankamai tikslią žemès fondo apskaitą. Pažymètina, kad neatitikimai tarp esamos padèties ir valstybinès žemès apskaitos buvo tik tose vietovèse, kuriose vyko savaiminè, natūrali žemès naudmenų transformacija, tačiau šie neatitikimai buvo nustatomi ir pašalinami atlikus pakartotinę žemès naudme- nų inventorizaciją. Iš žemės kadastro informacijos ${ }^{4}$ matyti, kad 1973-1985 m. laikotarpiu vidutiniškai per metus dèl savaiminès žemès naudmenų transformacijos žemès ūkio naudmenos Lietuvos žemès ūkio įmonèse mažèjo po 3,4 tūkst. ha, arba 0,1\%. Didesnių pokyčių leido išvengti melioracijos darbai, kurių metu vidutiniškai per metus žemès ūkio naudmenų plotas padidèdavo (dažniausiai - dèl krūmais apaugusių ir supelkejjusių buvusių žemès ūkio naudmenų ịsavinimo) po 14,3 tūkst. ha, arba po 15,3 ha (skaičiuojant 100 ha nusausintų žemès ūkio naudmenų ploto).

\footnotetext{
4 Aleknavičius P., Gogelis A., Jasinskas J., Pakutinskas J. ir kt. Žemes kadastras. Sud. J. Juodis, J. Pakutinskas. Vilnius, 1989.
} 
Po 1990 m. žeménaudų planai nebuvo atnaujinami, o turimuose planuose situacija koreguota tik juos naudojant žemès reformos žemètvarkos projektams rengti. Žemès naudmenų eksplikacijos (žemès kadastro rodiklių) turinys buvo supaprastintas paliekant tik tokias žemès naudmenų rūšis, kurių apskaita buvo reikalinga vertinant žemès našumą, nustatant žemès kainą ir žemètvarkos planavimo poreikiams. Neturint pradinès, tikslios medžiagos, žemès fondo apskaita buvo vykdoma tik administracinèms teritorijoms, o žemès naudmenų plotai, palyginti su praejusiais metais, buvo koreguojami minusuojant arba pridedant pakitusius žemès plotus dèl teisès aktais leistos žmogaus veiklos. Praktiškai šiuos pakitusius plotus sudarè sprendimai dèl žemès naudojimo paskirties pakeitimo, žemès paèmimas visuomenès poreikiams, išduoti leidimai įveisti mišką (nustačius, kad miškas pasodintas), informacija apie žemès panaudojimą statyboms ir kt. Todèl atsižvelgiant $\mathfrak{i}$ tai, kad per 1990-2010 m. laikotarpi sausinamosios melioracijos darbų apimtys sudare tik 105,2 tūkst. ha, žemès ūkio naudmenų ploto sumažèjimas dèl savaiminès jų transformacijos, nefiksuotas žemès apskaitos statistiniuose rodikliuose, gali siekti dar apie 0,5\% per metus.

Nauja žemès naudmenų kartografavimo tvarka yra numatyta žemès fondo apskaitos taisyklèse, patvirtintose Lietuvos Respublikos žemès ūkio ministro $2002 \mathrm{~m}$. rugpjūčio 7 d. ìsakymu Nr. 302 (Lietuvos Respublikos žemès ūkio ministro $2014 \mathrm{~m}$. sausio 28 d. ísakymo Nr. 3D-51 redakcija). Numatyta, kad žemės fondo valstybinę apskaitą nuo $2015 \mathrm{~m}$. bus rengiama naudojantis Žemès informacinèje sistemoje (toliau - ŽIS) sukauptais ir í vieną sistemą susietais erdviniais duomenimis apie žemę nustatant žemès naudmenas ir jų struktūrą. Žemès fondo valstybinè apskaita bus pildoma duomenimis apie Nekilnojamojo turto registre ịregistruotą pagrindinę žemès naudojimo paskirtị ir žemès naudotojų grupes, taip pat Laisvos valstybinès žemès fondo žemę ir Nacionalinès žemès tarnybos prie Žemès ūkio ministerijos (toliau - Nacionalinè žemès tarnyba) patikejjimo teise valdomą žemę.

Žemès fondo apskaitos suvestiniai duomenys bus rengiami kasmet pagal sausio $1 \mathrm{~d}$. būklę. Duomenys rengiami apie šalies teritoriją ir grupuojami pagal kadastro vietoves, miestus, savivaldybes, apskričių teritorijas.
Žemès fondo apskaitos duomenų parengimo atsakingoji institucija - VI Valstybės žemès fondas (toliau - Valstybės žemės fondas). Duomenis, kurių reikia žemès fondo apskaitai ir kurių Valstybès žemès fondas negali nustatyti naudodamasis ŽIS sukauptais ir ì vieną sistemą susietais erdviniais duomenimis, nustatyta tvarka Valstybès žemès fondui teikia Nacionalinè žemès tarnyba. Nekilnojamojo turto registro duomenų suvestines VI Registrų centras teikia Nacionalinei žemès tarnybai pagal duomenų teikimo sutartis.

Žemès fondo apskaitos duomenys rengiami pagal Lietuvos Respublikos nekilnojamojo turto kadastro įstatyme nustatytas žemès naudmenų rūšis bei Lietuvos Respublikos žemès įstatymo nustatytas pagrindinès žemès naudojimo paskirties kategorijas ir žemès nuosavybès bei valdymo formas, vadovaujantis Žemès informacinès sistemos nuostatais (Nacionalinès..., 2011). Duomenis apie žemès naudmenas bei apleistą žemę, naudodamas atskiruose teminiuose erdvinių duomenų rinkiniuose sukauptus ir ị vieną sistemą susietus erdvinius duomenis, parengia Valstybès žemès fondas. Žemès naudmenos nustatomos naudojantis šiomis duomenu bazèmis, esančiomis Žemès informacinèje sistemoje:

1) kartografinio pagrindo duomenys: Georeferencinio pagrindo kadastras (toliau - GRPK) valstybès kadastras, kuriame registruojami stabilūs žemés paviršiaus gamtiniai ir antropogeniniai objektai (kelių ašinès linijos, gatvių ašinès linijos, geležinkelių ašinès linijos, upių, upelių ašinès linijos, kanalų ir melioracijos griovių ašinès linijos, ežerų ir tvenkinių ribos, pastatų ribos, miškų naudmenų ribos, žemès ūkio naudmenų ribos, geodezinio pagrindo punktai, žemès paviršiaus (aukščio) taškai). Šio kadastro duomenis ir kadastro informaciją sudaro: kadastro duomenų rinkinys; valstybinis georeferencinių erdvinių duomenų rinkinys M 1:10 000 (GDR10LT); georeferencinio pagrindo žemèlapis. GRPK valdytojas yra Nacionalinè žemès tarnyba, o kadastro tvarkytojas - valstybès i̇monè Distancinių tyrimų ir geoinformatikos centras („GIS-Centras“);

2) valstybinių teminių erdvinių duomenų rinkinių duomenys:

- Lietuvos žemiu melioracinès būklès ir užmirkimo duomenų rinkinys Mel_DB10LT, kuriame saugoma informacija apie nusausintu (geros ir blogos melioracinès būklès) žemių plotus, nurašytos 
melioruotos žemès plotus ir nesausintų žemių plotus (M 1:10 000);

- Lietuvos Respublikos teritorijos apleistų žemių duomenų rinkinys AŽ_DB10LT, kuriame saugoma informacija apie neprižiūrimas, nenaudojamas arba netinkamas naudoti pagal nustatytą pagrindinę žemès naudojimo paskirtị žemès ūkio naudmenas.

Nusausintos žemès ir drèkinamos žemės erdvinius ir suvestinius statistikos duomenis, naudojantis Lietuvos žemių melioracinès būklès ir užmirkimo duomenų bazès Mel_DR10LT duomenimis, parengia Valstybès žemès fondas.

GDR duomenys ir (arba) kadastro informacija keičiami pagal:

- ne senesnio kaip 5 metų Lietuvos Respublikos teritorijos M 1:5 000 arba M 1:10 000 skaitmeninio rastrinio ortofotografinio žemèlapio informaciją;

- Lietuvos Respublikos teritorijos skaitmeninius erdvinius žemès paviršiaus lazerinio skenavimo taškų duomenis;
- kadastro duomenų teikejų pateiktus dokumentus ir (arba) duomenis;

- kadastro tvarkytojo atliktų lauko patikrų duomenis, jam pastebejus atsiradusius naujus ar išnykusius objektus, kitus kadastro duomenų ir (arba) informacijos pasikeitimus.

Naudojantis ortofotografiniu žemèlapiu ar nuotolinio skenavimo duomenimis, kadastro duomenys ir (arba) kadastro informacija pakeičiami ne vèliau kaip per vienus metus nuo ortofotografinio žemèlapio sudarymo ar nuotolinio skenavimo duomenu parengimo datos (Lietuvos..., 2013).

Nauja žemės fondo apskaitos tvarka leistų šalies mastu rengti kartografinę medžiagą - žemès naudojimo žemèlapius, kurie kartu su kita ŽIS skaitmenine kartografine informacija būtų naudojama rengiant teritorijų planavimo dokumentus. Tai ypač svarbu planuojant agrarines teritorijas, kuriose kvalifikuotai parengti kaimo plètros žemètvarkos projektai ir kiti specialieji planai turètų numatyti racionalaus žemès naudojimo reikalavimus atitinkantị

2 lentelè. Statistinių ir naudojamų žemès ūkio naudmenų ploto kitimo dinamika Lietuvoje 2003-2014 m.

Table 2. Dynamics of statistical and used farming land area changes in Lithuania, 2003-2014

\begin{tabular}{|c|c|c|c|c|c|c|}
\hline \multirow{3}{*}{$\begin{array}{l}\text { Eil. } \\
\text { Nr. } \\
\text { No. }\end{array}$} & \multirow{3}{*}{$\begin{array}{c}\text { Me- } \\
\text { tai } \\
\text { Year }\end{array}$} & \multicolumn{3}{|c|}{$\begin{array}{l}\text { Žemès ūkio naudmenų plotas tūkst. ha } \\
\text { Farming land area, thous. ha }\end{array}$} & \multirow{2}{*}{\multicolumn{2}{|c|}{$\begin{array}{c}\text { Skaičiuojamas } \\
\text { nepanaudotų (apleistų bei } \\
\text { dirvonuojančių) žemès ūkio } \\
\text { naudmenų plotas } \\
\text { Calculated unused (fallow } \\
\text { and abandoned) farming } \\
\text { land area }\end{array}$}} \\
\hline & & \multirow{2}{*}{$\begin{array}{l}\text { Žemès fondo } \\
\text { apskaitos } \\
\text { duomenys } \\
\text { By land fund } \\
\text { registration } \\
\text { data }\end{array}$} & \multirow{2}{*}{$\begin{array}{l}\text { Visuotinio žemès } \\
\text { ūkio surašymo } \\
\text { duomenys } \\
\text { By Census of } \\
\text { Agriculture data }\end{array}$} & \multirow{2}{*}{$\begin{array}{c}\text { Žemès ūkio } \\
\text { naudmenų ir pasèlių } \\
\text { deklaravimo } \\
\text { duomenys } \\
\text { By agriculture land } \\
\text { and crops declaration } \\
\text { data }\end{array}$} & & \\
\hline & & & & & $\begin{array}{l}\text { tūkst. ha } \\
\text { thous. ha }\end{array}$ & $\begin{array}{l}\text { proc. } \\
\text { percent }\end{array}$ \\
\hline 1. & 2003 & 3313,9 & 2491,0 & - & 822,9 & 24,8 \\
\hline 2. & 2004 & 3312,4 & - & 2571,5 & 740,9 & 22,4 \\
\hline 3. & 2005 & 3313,3 & - & 2561,2 & 752,1 & 22,7 \\
\hline 4. & 2006 & 3310,6 & - & 2613,4 & 697,2 & 21,1 \\
\hline 5. & 2007 & 3311,1 & - & 2629,6 & 681,5 & 20,6 \\
\hline 6. & 2008 & 3309,5 & - & 2615,8 & 693,7 & 21,0 \\
\hline 7. & 2009 & 3311,1 & - & 2637,6 & 673,5 & 20,3 \\
\hline 8. & 2010 & 3308,9 & 2742,6 & 2681,0 & 627,9 & 19,0 \\
\hline 9. & 2011 & 3308,1 & - & 2728,4 & 579,7 & 17,5 \\
\hline 10. & 2012 & 3310,6 & - & 2758,8 & 551,8 & 16,7 \\
\hline 11. & 2013 & 3306,3 & - & 2776,6 & 529,7 & 16,0 \\
\hline 12. & 2014 & 3304,2 & - & 2813,9 & 490,3 & 14,8 \\
\hline
\end{tabular}

Pastaba: be miestuose ir sodininkų bendrijų soduose esančių žemės ūkio naudmenų;

** be deklaruotų plotų, kuriuos užima miško sodiniai ir kiti ne žemès ūkio augalai.

Note: ${ }^{\star}$ excluding the agricultural land located in cities and gardens of gardening communities;

** excluding the declared area occupied by forest plantations and other non-agricultural plants. 
žemès ūkio naudmenų ir natūralių arba sąlyginai natūralių kitų žemès naudmenų išsidèstymą.

\section{Žemès ūkio naudmenų pokyčių tyrimai}

Socialiniu ir ekonominiu sąlygu ịtaka žemès ūkio paskirties žemés naudojimo intensyvumui. Didžiausią įtaką šalies žemès ūkio paskirties žemès naudojimo intensyvumui padare $1991 \mathrm{~m}$. pradèta agrarinè reforma, iš esmès pakeitusi ūkininkavimo formas, žemès valdymo ir naudojimo santykius bei žemès ūkio veiklos subjektų gamybinius pajègumus. Dèl šių priežasčių žemés ūkio paskirties žemèje esančių naudojamų žemès ūkio naudmenų plotas per 1989-2003 m. laikotarpi sumažejo nuo 3373 tūkst. ha iki 2491 tūkst. ha (26,1\%), arba mažèjo vidutiniškai po 63 tūkst. ha per metus. Vèliau dèl ES ir valstybès biudžeto teikiamos paramos žemès ūkio ir kaimo plètrai naudojamų žemès ūkio naudmenų plotas pradejo didèti: per 2003-2014 m. laikotarpi jis padidejo vidutiniškai $13 \%$, arba didèjo po 29 tūkst. ha kasmet (2 lentelè).

Siekiant nustatyti realų žemès ūkio naudmenų plotą, buvo išnagrinèta Lietuvoje ir administracinèse teritorijose:

- VIt Registrų centro parengti žemès valstybinès apskaitos duomenys 20110101 (žemès ūkio paskirties žemėje esančios žemès ūkio naudmenos, be sodininkų bendrijų sodų);

- Statistikos departamento skelbiami Visuotinio žemès ūkio surašymo duomenys apie ūkių naudojamas žemès ūkio naudmenas 2003 ir 2010 m.;

- Nacionalinès mokejjimo agentūros skelbiami žemès ūkio naudmenų ir pasèlių deklaravimo duomenys (2004-2014).

Palyginus šiuos duomenis kaimiškujų savivaldybių teritorijose, nustatyti skirtumai leidžia spręsti apie nuokrypius nuo statistinio žemès ūkio naudmenų ploto įvairiose šalies vietovèse. Skirtumas, išreikštas plotu ir procentais, rodo žemès ūkio naudmenų nepanaudojimo laipsni (S). Jis apima plotą, kuris gali būti jau ne žemès ūkio naudmenos (buvusios žemès ūkio naudmenos, dèl savaiminès transformacijos natūraliai pavirtę miškais, medžių ir krūmų želdiniais, pelkèmis ir kitomis nenaudojamomis žemėmis), bei plotą, kuris priskirtinas tik dirvonuojančioms bei kitoms nenaudojamoms žemès ūkio naudmenoms. Duomenų nustatymo patikimumą rodo skirtingi statistiniai šaltiniai, todèl priimti šie nukrypimo nuo statistinio ploto rodikliai: $S_{1}$ - skirtumas nuo statistinio ploto ir ploto, apskaičiuoto pagal $2010 \mathrm{~m}$. Visuotinio žemès ūkio surašymo duomenis, išreikštas procentais; $S_{2}$ - skirtumas nuo statistinio ploto ir ploto, apskaičiuoto pagal $2011 \mathrm{~m}$. žemès ūkio naudmenų deklaravimo duomenis, išreikštas procentais.

Gauta daugialypès regresijos lygtis:

$$
S_{1}=\frac{2476,57}{X_{1}}+0,0028 \mathrm{X}_{2}^{2} 245,77 \text {; }
$$

$S_{1}$ - žemès ūkio naudmenų nepanaudojimo laipsnis (skirtumas nuo statistinio žemès ūkio naudmenų ploto ir ploto, apskaičiuoto pagal $2010 \mathrm{~m}$. Visuotinio žemès ūkio surašymo duomenis, procentais);

$X_{1}$ - žemès našumo balas, apskaičiuotas pagal VI Registru centro duomenis, nustačius Nekilnojamojo turto registre 20110101 iregistruotu 1056 tūkst. žemès sklypų našumo balo vidutinị aritmetinị vidurkį;

$X_{2}$ - kaimo gyventojų skaičius $2011 \mathrm{~m}$. pradžioje, tenkantis 100 ha žemès ūkio paskirties žemès ploto.

Šios daugialypès koreliacijos koeficientas $r=0,65$, determinacijos koeficientas $R^{2}=0,42$ esant patikimumo lygmeniui $t>2,5$. Likusius $58 \%$ lemia kiti tyrimuose neišnagrinèti veiksniai.

Panaši koreliacinė priklausomybè nustatyta ir palyginus $2011 \mathrm{~m}$. žemès ūkio naudmenų deklaravimo duomenis savivaldybèse su statistiniu šių naudmenų plotu (skirtumas išreikštas procentais rodo žemès ūkio naudmenų nepanaudojimo laipsni $\left.-S_{2}\right)$. Gauta daugialypés regresijos lygtis:

$$
S_{2}=\frac{2739,73}{X_{1}}+0,0034 X_{2}^{2}-52,24 \text {. }
$$

Nustatytas koreliacijos koeficientas $r=0,686$, determinacijos koeficientas $R^{2}=0,47$ esant patikimumo lygmeniui $t>3$.

Atlikti nepanaudoto ploto statistiniai tyrimai parodè, kad mažejjant našumo balui bei kaimo gyventojų skaičiui administracinèse teritorijose didèja nepanaudotų plotų.

Darant prielaidą, kad didžiausias žemès ūkio naudmenų ploto sumažèjimas yra nederlingus dirvožemius turinčiose vietovèse (kur ūkininkauti žemès reformos pradžioje buvo ekonomiškai neefektyvu), tirta rodiklio $S$ priklausomybė nuo vidutinio žemès ūkio naudmenų našumo balo $\left(X_{1}\right)$. Žemès ūkio naudmenų nepanaudojimo laipsnio rodiklio, apskaičiuoto pagal Visuotinio žemès ūkio 
surašymo duomenis, priklausomybè nuo žemès našumo balo pavaizduota 1 pav.

Nepanaudotų žemès ūkio veiklai žemès ūkio naudmenų ploto procentas, apskaičiuoto pagal 2011 m. žemès ūkio naudmenų ir pasèlių deklaravimo duomenis, priklausomybè nuo vidutinio žemès našumo balo yra labai panaši kaip ir $2010 \mathrm{~m}$. $\left(R^{2}=0,356\right)$.

Žemès našumo balas yra tik apibendrinantis, sintetinis rodiklis, kuris ịvertina įvairias žemès savybes, išreikštas informacinių duomenų bazèse. Priklausomai nuo dirvožemio tipo, granuliometrinès sudèties, drègmès režimo, humusingumo, rūgštumo, judriojo fosforo ir kalio gausumo, skiriasi ir auginamų pasèlių plotai bei gaunamos pajamos iš žemès ūkio veiklos. Siekiant nustatyti žemès naudojimo intensyvumo rodiklius (I), apskaičiuoti žemès ūkio naudmenų plotai be ekstensyviai naudojamų augalų (jiems priskirta pievos, ganyklos ir daugiametès žolès) ir be juodiesiems pūdymams skirto ploto. Duomenys apskaičiuoti panaudojant skirtingus informacijos šaltinius, todèl priimti tokie rodikliai:

$I_{1}$ - žemès naudojimo intensyvumo rodiklis: žemès ūkio naudmenos be ekstensyviai naudojamų augalų ir juodųjų pūdymų, proc. nuo viso žemès ūkio naudmenų ploto (apskaičiuota pagal $2010 \mathrm{~m}$. Visuotinio žemès ūkio surašymo duomenis);

$I_{2}$ - žemès naudojimo intensyvumo rodiklis: žemès ūkio naudmenos be ekstensyviai naudo- jamų augalų ir juodujų pūdymų, proc. nuo viso žemès ūkio naudmenų ploto (apskaičiuota pagal 2011 m. žemès ūkio naudmenų ir pasèlių deklaravimo duomenis);

$X_{1}$ - žemès našumo balas.

Atlikus savivaldybių teritorijų rodiklių porinès koreliacijos analizę, nustatyta stipri žemès naudojimo intensyvumo priklausomybė nuo žemės našumo:

$$
I_{1}=3,14 X_{1}-78,45
$$

(determinacijos koeficientas $R^{2}=0,6684$ );

$$
\begin{aligned}
& I_{2}=2,7833 X_{1}-58,624 \\
& \left(\text { determinacijos koeficientas } R^{2}=0,5914\right) .
\end{aligned}
$$

Be to, intensyviau naudojančiose žemès ūkio naudmenas savivaldybèse gaunama daugiau ir didesnę vertę turinčios augalininkystès produkcijos (2 pav.).

Iš tyrimo duomenų galima spręsti, jog didžiausi rezervai naudojamų žemès ūkio naudmenų plotui padidinti ir ploto vienetui tenkančiai žemès ūkio produkcijai padidinti yra teritorijose, kurių žemès našumas mažesnis nei 42-45 balai, taip pat tose savivaldybėse, kur išauginamos augalininkystès produkcijos vertè yra mažesnè nei $1500 \mathrm{Lt} / \mathrm{ha}$.

Reljefo įtaka žemès ūkio naudmenu naudojimo intensyvumui. Tyrimų metu šalies kaimiškosios savivaldybės buvo grupuojamos pagal jų teritorijoje

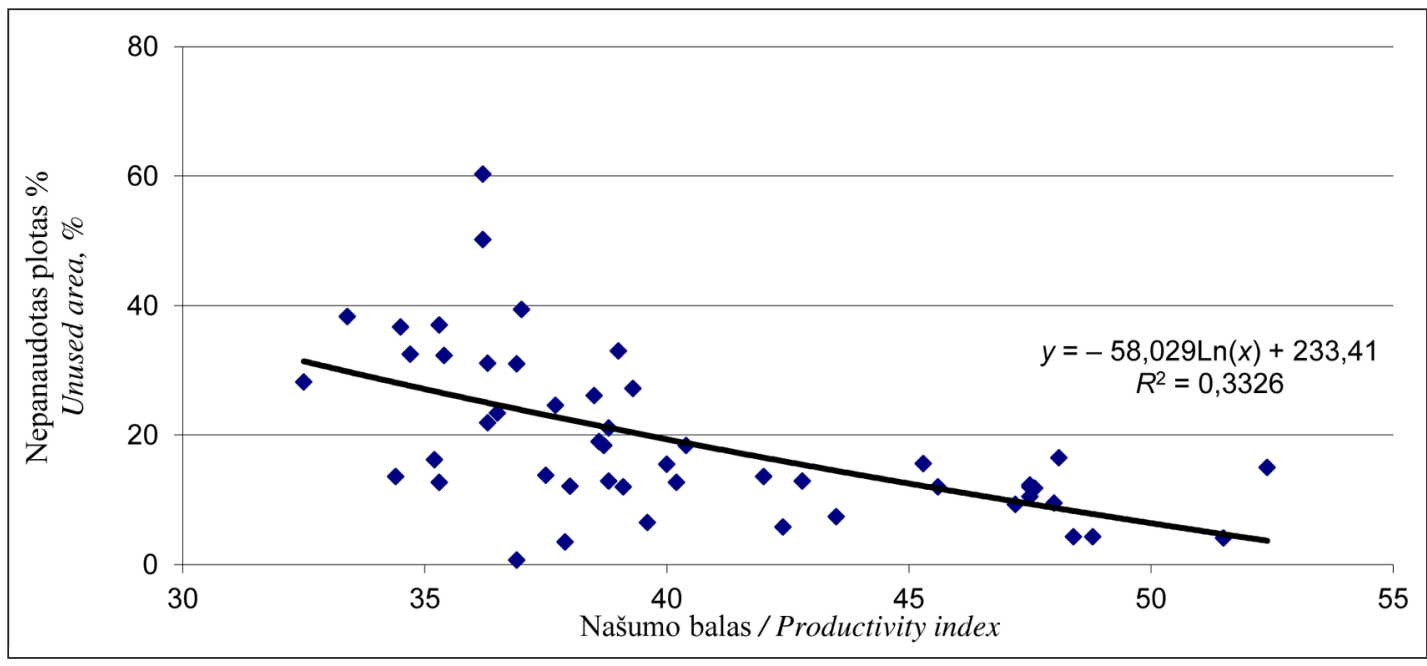

1 pav. Nepanaudotų žemès ūkio veiklai žemės ūkio naudmenų ploto (apskaičiuoto pagal $2010 \mathrm{~m}$. Visuotinio žemės ūkio surašymo duomenis, \%) priklausomybė nuo vidutinio žemès našumo balo Lietuvos savivaldybèse

Fig. 1. Dependence of unused agricultural land area (calculated using Census of Agriculture data (2010), \%) on average soil productivity index in municipalities of Lithuania 


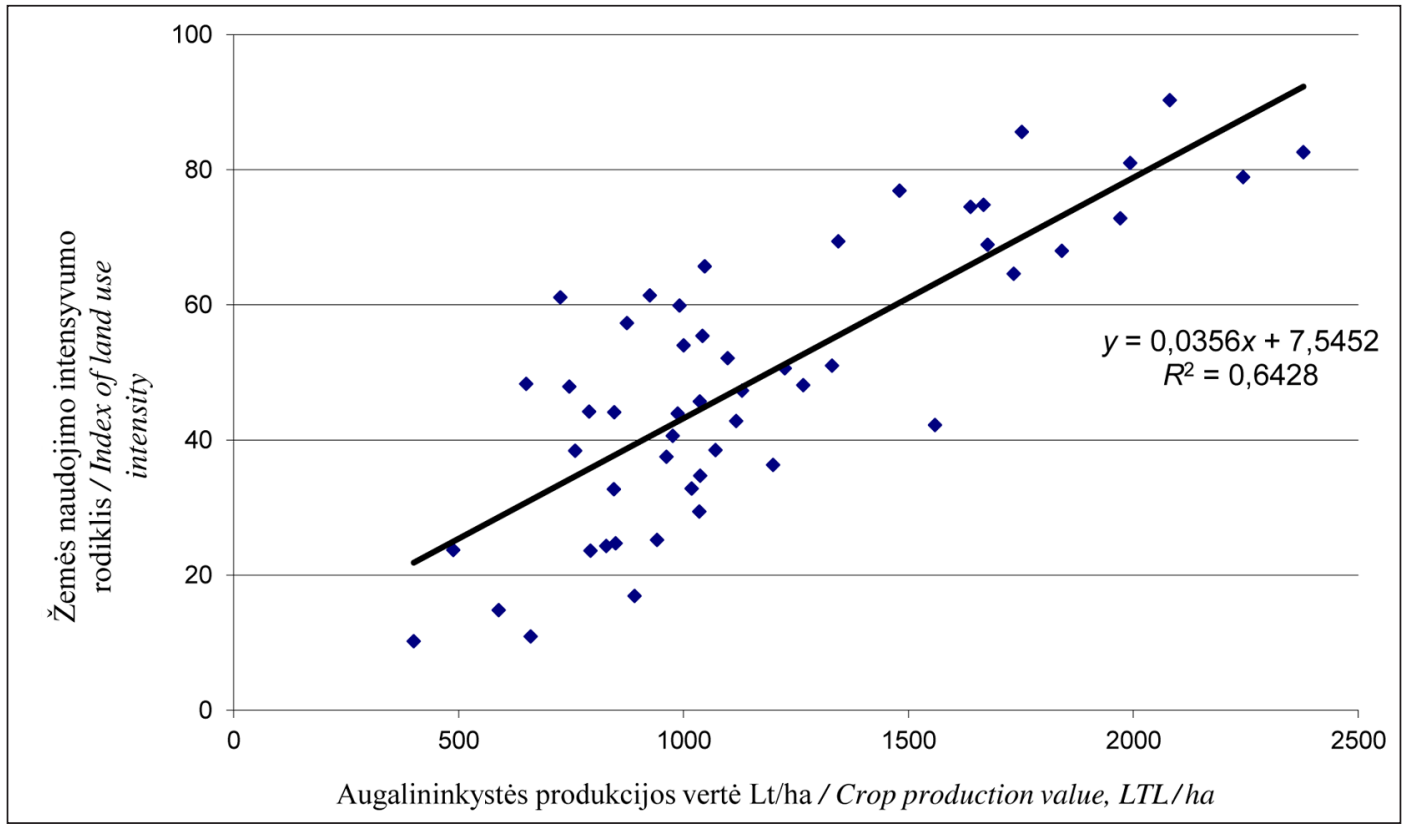

2 pav. Žemès naudojimo intensyvumo rodiklio priklausomybè nuo augalininkystès produkcijos vertès Lt/ha Lietuvos savivaldybèse (2010 m. Visuotinio žemės ūkio surašymo duomenys)

Fig. 2. Index of land use intensity dependence on crop production value LTL/ha in municipalities of Lithuania (using Census of Agriculture data (2010))

vyraujantị reljefą. Išnagrinejjus kartografinę medžiagą apie dirvožemius ir reljefo formas bei šlaitų nuolydžius nustatyta, jog 23 kaimiškosios savivaldybès gali būti priskirtos teritorijoms su vyraujančiu kalvotu ir banguotu reljefu (kalvoto reljefo plotai yra su statesniais nei $5^{\circ}$ šlaitų polinkiais, banguoto reljefo $-2^{\circ}-5^{\circ}$ šlaitų polinkiais), o likusios 28 kaimiškosios savivaldybès - teritorijoms su vyraujančiu lyguminiu reljefu. Kalvotosios savivaldybės dar išskirtos ị mažo kalvotumo (jose kalvotas reljefas yra 13-60\% teritorijos, banguotas - 45$85 \%$ ) ir vidutinio kalvotumo (jose kalvotas reljefas - 56-96 \% teritorijos, banguotas - 4-45\%). Likusiose lyguminio reljefo savivaldybèse teritorijos su banguotu reljefu sudaro ne daugiau kaip $49 \%$, kalvotu reljefu - $25 \%$, bendras - ne daugiau kaip $55 \%$. Savivaldybių išsidèstymas pateiktas 3 pav., o atskirose grupèse nustatytas žemès naudojimo intensyvumas - 3 lenteleje.

Kaip matyti iš 3 lentelès, kalvotų teritorijų savivaldybėse žemès ūkio paskirties žemé Lietuvoje sudaro $40,0 \%$, statistinès žemès ūkio naudmenos - 37,0 \%, naudojamos (deklaruotos) žemès ükio naudmenos - 32,6 \% viso šio ploto. Lyginant su savivaldybèmis, kuriose vyrauja lyguminis ir banguotas reljefas, kalvotų teritorijų savivaldybèse vidutinis žemès našumo balas yra $19 \%$ ma- žesnis, o nedeklaruotų žemès ūkio naudmenų santykinè dalis visose (pagal statistinę apskaitą nustatytose) žemès ūkio naudmenose - 2,7 karto didesnè. Tai galima paaiškinti kalvotose vietovése vyraujančiais mažesnès ūkinès vertès bei nuardytais dirvožemiais, didesne žemès naudmenų sąskaida, smulkesniais ariamosios žemès, pievų ir ganyklų sklypais, mechanizuotam žemès dirbimui mažiau tinkama sklypų konfigūracija, žemès ūkio produkciją auginančių ūkių mažesniais gamybiniais pajègumais, ribojančiais spartesni gamybos intensyvinimą. Siekiant racionalaus žemès naudojimo, šių teritorijų žemės apskaitą tikslinga sieti su ŽIS duomenimis, apibūdinančiais potencialų dirvožemio derlingumą ir kitas žemès ūkines savybes. Tai leistų kartografinès medžiagos atnaujinimo metu pateikti rekomendacijas, kaip pagerinti apleistų ir dirvonuojančių žemès ūkio naudmenų būklę, taip pat išskirti buvusių žemès ūkio naudmenų plotus, juos palikti natūraliai transformuotis iš apleistų žemių ị kitas naudmenas arba rekomenduoti apsodinti mišku. Rengiant agrarinių teritorijų planavimo dokumentus, kalvotų teritorijų savivaldybėse tikslinga naudoti ne tik žemès naudojimo žemèlapius su pažymètais žemès naudmenų kontūrais, bet ir hipsometrinius planus. 


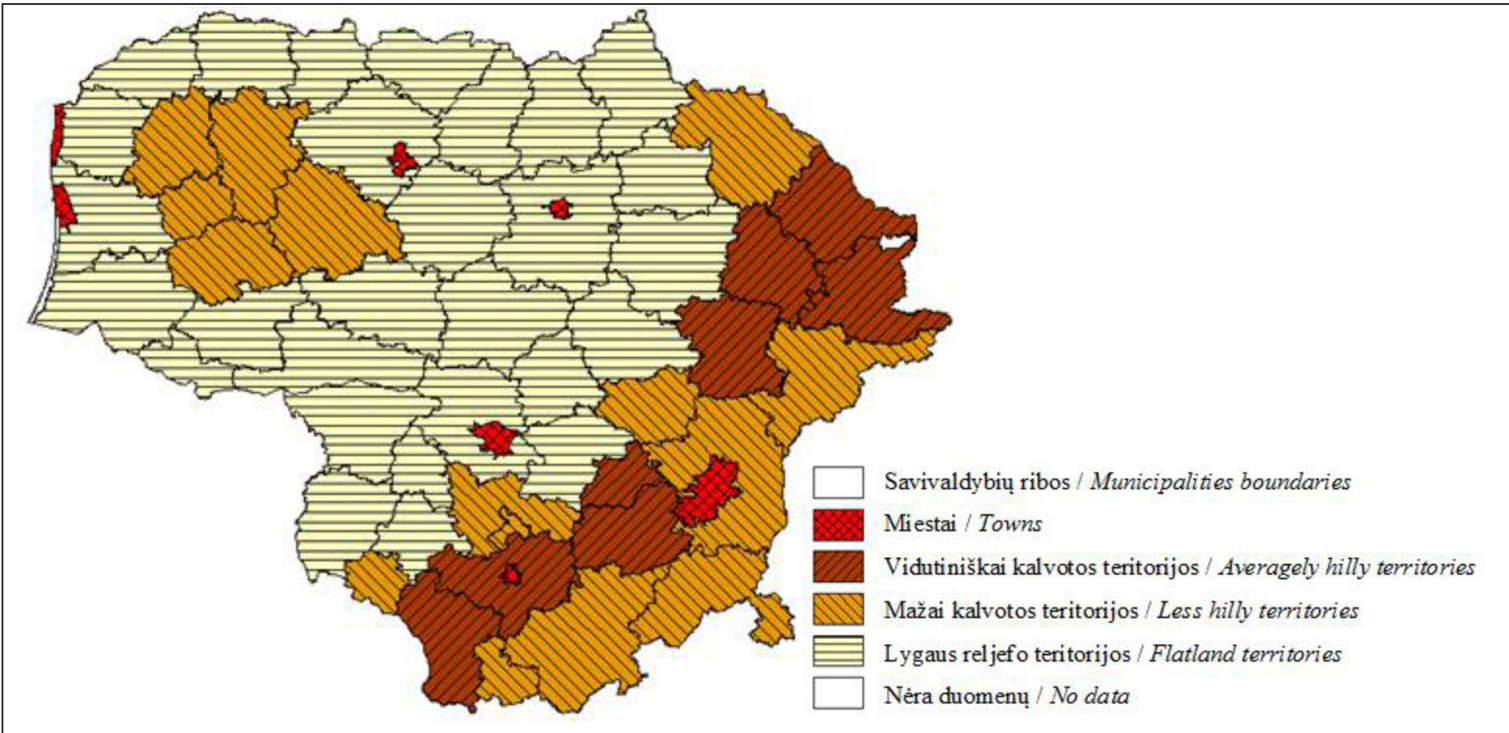

3 pav. Savivaldybės su agrarinėse teritorijose vyraujančiu kalvotu ir banguotu reljefu Fig. 3. Municipalities with hilly and rolling relief dominating in agrarian territories

3 lentelè. Reljefo ịtaka kaimiškųjų savivaldybių žemès ūkio paskirties žemės naudojimo intensyvumui

Table 3. Relief influence on agricultural land use intensity of rural municipalities

\begin{tabular}{|c|c|c|c|c|c|c|c|}
\hline \multirow{2}{*}{$\begin{array}{l}\text { Eil. } \\
\text { Nr. } \\
\text { No. }\end{array}$} & \multirow[b]{2}{*}{$\begin{array}{l}\text { Rodikliai } \\
\text { Indicators }\end{array}$} & \multirow{2}{*}{$\begin{array}{l}\text { Matavimo } \\
\text { vnt. } \\
\text { Unit }\end{array}$} & \multicolumn{3}{|c|}{$\begin{array}{l}\text { Kalvotos teritorijos } \\
\text { Hilly territories }\end{array}$} & \multirow{2}{*}{$\begin{array}{l}\text { Lygumines } \\
\text { teritorijos } \\
\text { Flatland } \\
\text { territories }\end{array}$} & \multirow[b]{2}{*}{$\begin{array}{l}\text { Iš viso } \\
\text { Total }\end{array}$} \\
\hline & & & $\begin{array}{c}\text { vidutiniškai } \\
\text { kalvotos } \\
\text { Averagely hilly }\end{array}$ & $\begin{array}{l}\text { mažai } \\
\text { kalvotos } \\
\text { Less hilly }\end{array}$ & $\begin{array}{l}\text { iš viso } \\
\text { Total }\end{array}$ & & \\
\hline 1. & $\begin{array}{l}\text { Savivaldybių skaičius } \\
\text { Number of municipalities }\end{array}$ & $\begin{array}{l}\text { vnt. } \\
\text { unit }\end{array}$ & 8 & 15 & 23 & 28 & 51 \\
\hline \multirow{2}{*}{2.} & \multirow{2}{*}{$\begin{array}{l}\text { Žemès ūkio paskirties } \\
\text { žemé } 20140101^{1} \\
\text { Agricultural land }\end{array}$} & $\begin{array}{l}\text { tūkst. ha } \\
\text { thous. ha }\end{array}$ & 577,1 & 985,9 & 1563,0 & 2347,1 & 3910,0 \\
\hline & & $\begin{array}{l}\text { \% šalyje } \\
\% \text { in country }\end{array}$ & 14,8 & 25,2 & 40,0 & 60,0 & 100,0 \\
\hline \multirow{2}{*}{3.} & \multirow{2}{*}{$\begin{array}{l}\text { Iš to ploto - žemès ūkio } \\
\text { naudmenos } \\
\text { Farming lands in agricul- } \\
\text { tural land area }\end{array}$} & $\begin{array}{l}\text { tūkst. ha } \\
\text { thous. ha }\end{array}$ & 427,4 & 811,2 & 1238,6 & 2106,6 & 3345,2 \\
\hline & & $\begin{array}{c}\text { \% šalyje } \\
\% \text { in country }\end{array}$ & 12,8 & 24,2 & 37,0 & 63,0 & 100,0 \\
\hline \multirow{2}{*}{4.} & \multirow{2}{*}{$\begin{array}{c}2014 \text { m. deklaruotos } \\
\text { žemès ükio naudmenos } \\
\text { Farming lands declared } \\
\text { in } 2014\end{array}$} & $\begin{array}{l}\text { tūkst. ha } \\
\text { thous. ha }\end{array}$ & 289,2 & 627,2 & 916,5 & 1896,1 & 2812,6 \\
\hline & & $\begin{array}{c}\text { \% šalyje } \\
\% \text { in country }\end{array}$ & 10,3 & 22,3 & 32,6 & 67,4 & 100,0 \\
\hline \multirow{2}{*}{5.} & \multirow{2}{*}{$\begin{array}{l}2014 \text { m. nedeklaruotos } \\
\text { žemès ükio naudmenos } \\
\text { Farming lands undeclared } \\
\text { in } 2014 \\
\end{array}$} & $\begin{array}{l}\text { tūkst. ha } \\
\text { thous. ha }\end{array}$ & 138,1 & 184,0 & 322,1 & 210,5 & 532,6 \\
\hline & & $\%$ & 25,9 & 34,6 & 60,5 & 39,5 & 100 \\
\hline \multirow[t]{2}{*}{6.} & \multirow{2}{*}{$\begin{array}{c}\text { Iš jų - apleistos žemès } \\
\text { ūkio naudmenos } \\
\text { Abandoned farming lands }\end{array}$} & $\begin{array}{l}\text { tūkst. ha } \\
\text { thous. ha }\end{array}$ & 54,1 & 70,4 & 124,5 & 66,2 & 190,7 \\
\hline & & $\%$ & 39,2 & 38,3 & 38,7 & 31,4 & 35,8 \\
\hline 7. & $\begin{array}{l}\text { Vidutinis žemès ūkio } \\
\text { naudmenų našumo balas } \\
\text { Average farming land } \\
\text { productivity index }\end{array}$ & $\begin{array}{l}\text { balai } \\
\text { Index }\end{array}$ & 36,0 & 36,8 & 36,5 & 45,1 & 41,85 \\
\hline
\end{tabular}

1 Valstybinės apskaitos duomenys (žemé; be sodininkų bendrijų sodų).

22014 m. VŽF duomenys (plotas). 


\section{IŠVADOS}

1. Planuojant žemès ūkio veiklą ir racionaliai naudojant žemès ūkio paskirties žemę svarbu turèti patikimą informaciją apie žemès ūkio naudmenų išsidèstymą ir jų ploto pasiskirstymą pagal žemès naudojimo intensyvumą apibūdinančius požymius. Tiksli žemès naudmenų apskaita gali būti užtikrinama tik turint kartografuotus žemès naudmenų kontūrus ir periodiškai atnaujinant pakitusią situaciją, juo labiau kad tobulejjanti matavimų technika bei kadastro duomenų panaudojimo poreikis tai leidžia atlikti. Šią informatyvią medžiagą galima parengti igyvendinant teisès aktus, reglamentuojančius šalies žemès fondo valstybinès apskaitos ir žemès informacinès sistemos tvarkymą.

2. Daugiausia nepanaudotų žemés ūkio produkcijai auginti žemès ūkio naudmenų yra teritorijose su erozijos paveiktais dirvožemiais, iš ju - kalvoto reljefo savivaldybėse, kur vyrauja mažos ūkinès vertès, smulkūs ir mechanizuotam dirbimui nepatogūs žemès ūkio naudmenų kontūrai.

3. Nenaudojamos žemès ūkio naudmenos Lietuvoje kasmet mažeja, o naudojamos (deklaruojamos) žemès ūkio naudmenos nuo 2004 iki 2014 m. didejo vidutiniškai po 24 tūkst. ha per metus. Tai rodo, kad dali apleistų bei dirvonuojančiu žemès ùkio naudmenų galima pradèti naudoti be papildomų žemès melioracinių priemonių. Kol šios žemès ūkio naudmenos nepavirto miškais, medžių ir krūmų augalija ar pelkèmis, jų plotus būtina identifikuoti nustatant tikslingiausio panaudojimo perspektyvas.

4. Žemès ūkio naudmenu kartografavimas ir apskaitos patikslinimas pirmiausiai reikalingas kalvotose teritorijose su nenašiomis žemèmis, kadangi jose yra santykinai didesni apleistų žemių ir ekstensyviai naudojamų žemès ūkio naudmenų plotai. Be to, šiuos darbus tikslinga vykdyti ir urbanistinès plètros arealuose, pasižyminčiuose didesne kaimo gyventojų koncentracija ir intensyviausiais žemės naudmenų sudèties pokyčiais.

Gauta 20140903

Priimta 20141210

\section{LITERATŪRA}

1. Abalikštienė E., Aleknavičius P. 2013. Žemès ūkio paskirties žemès naudojimo tendencijos nenašių žemių savivaldybèse. Žemés ūkio mokslai. T. 20. Nr. 3. P. 159-169.

2. Aleknavičius P., Aleknavičius A., Juknelienè D. 2014. Agrariniu teritoriju naudojimo problemos ir jų sprendimas Lietuvoje. Žemès ūkio mokslai. T. 21. Nr. 2. P. $78-88$.

3. Aleknavičius A., Aleknavičius P. 2010. Žemès ūkio naudmenų ploto pokyčių perspektyvos Lietuvoje. Vagos. Nr. 86(39). P. 28-36.

4. Aleknavičius P., Stravinskienè V. 2011. Žemès savybiu itaka žemès ūkio plètrai Lietuvoje. Kaimo raidos kryptys žiniu visuomenèje. Nr. 2. P. 188-198.

5. Aleknavičius P., Valčiukienè J. 2011. Kaimiškojo kraštovaizdžio raidos ypatumai Vilniaus miesto itakos zonoje. Vandens ūkio inžinerija. Nr. 38(58). P. 32-41.

6. Aleknavičius P. 2003. Žemès naudmenu apskaita kaimo vietovèje. Žemés ūkis. Nr. 1. P. 9-11.

7. Aleknavičius P. 2007. Kaimiškụjų teritorijų žemès naudojimo problemos. Žemés ükio mokslai. T. 14. Nr. 1. P. 82-90.

8. Aleknavičius P. 2012. Kaimiškujų teritorijų tvarkymo reguliavimas. Darnaus vystymosi strategija ir praktika. T. 1. Nr. 6. P. 111-122.

9. Kavaliauskienè B., Tarvydienè M. E. 2005. The Change of the Agricultural Land and Forest Areas in Lithuania in 1982-2002. Vagos. Nr. 67(20). P. 64-68.

10. Lietuvos Respublikos Vyriausybés $2013 \mathrm{~m}$. kovo 13 d. nutarimas Nr. 215. „Dèl georeferencinio pagrindo kadastro steigimo, jo nuostatu patvirtinimo ir veikimo pradžios nustatymo".

11. Lietuvos žemès našumas: monografija. Sud. J. Mažvila. 2011. Akademija, Kèdainiu r.: Lietuvos žemdirbystès institutas. $280 \mathrm{p}$.

12. Nacionalinès žemès tarnybos prie Žemès ūkio ministerijos direktoriaus $2011 \mathrm{~m}$. lapkričio $22 \mathrm{~d}$. ịsakymas Nr. 1P-(1.3.)-267 „Dèl žemés informacinès sistemos nuostatu ir žemes informacines sistemos duomenu saugos nuostatu patvirtinimo".

13. Rutkauskaitè R., Milius J. 2007. Lietuvos žemès fondo apskaitos ypatumai XX a. Bakalauro darbas. Vilniaus universitetas.

14. Stravinskienė V. 2002. Ariamosios žemès naudojimo pokyčiai Vidurio Lietuvos rajonuose. Vandens ükio inžinerija: mokslo darbai. Kaunas-Akademija; Vilainiai. Nr. 21(43). P. 80-84.

15. Stravinskienė V. 2006. Žemès ūkio naudmenu struktūros pasikeitimai Lietuvos ir Europos agrarinėse teritorijose. Matavimu inžinerija ir GIS: respublikine moksliné-praktiné konferencija: straipsniu rinkinys. Mastaičiai. P. 70-73.

16. Šiupinyte R., Mačiulytè J. 2013. Žemès ūkio naudmenu dinamika Baltijos šalyse atkūrus nepriklausomybę. Bakalauro darbas. Vilnius: Vilniaus universitetas. 
Agnẻ Bykovienė, Darius Pupka, Audrius Aleknavičius

\section{ANALYSIS OF AGRICULTURAL LAND AREA REGISTRATION AND ITS CHANGES IN LITHUANIA}

\section{Sum $m$ ary}

This article studies land fund registration data and its implementation procedure. It analyses the changes of agricultural land in Lithuania and factors of influence towards these changes. Dependence between soil productivity, location relief and the rate of land use for agricultural production purposes was estimated. There are 23 hilly municipal territories which have poor conditions for land use because of its rolling, hilly relief, thus relatively there are more of unused (undeclared) agricultural land. In order to estimate agricultural land area more accurately, it is recommended to arrange and periodically renew mapping data with marked agriculture land outlines by implementing remote researches and then applying this data to the land fund registration. Land Information System, which holds the data of agricultural land parcel farming characteristics, should include mapping of land use and hypsometric maps of hilly territories. This mapping and land fund registration data should be used for agrarian territory management and land improvement planning. Agricultural land mapping and more accurate registration of its area are essential in hilly territories and urban development areas.

Key words: stock of land, agricultural land, hilly territories, soil productivity index, land mapping, land fund registration 